\title{
Princípios Fundamentais da Lei de Reforma Administrativa, no Tocante ao Pessoal
}

\section{LUIZ VICENTE BELFORT DE OURO PRETO}

Técnico de Administração. Ex-Diretor-Geral do DASP. "L'Administration ce sont les hommes".

* * * *

"Government is not a machine, but a living organism" (Franklin D. Roosevelt).

$$
* * *
$$

"Valorização e dignificação da função pública e do servidor público"

"Profissionalização e aperfeiçoamento do servidor público" "Fortalecimento do sistema do mérito"

"Retribuição baseada na classificação das funções" (art. 94, incisos I, III e VI, do Decreto-lei n? 200, de 25-2-67).

\section{INTRODUÇÃO}

O crescimento incessante da Administração Pública é simples e fôrça da decorrência da atuação do Estado, cada vez mais extensa e intensa, em todos os setores da vida nacional. Dia a dia assume o Poder Público novas atribuições e responsabilidades cujos encargos recaem sôbre os órgãos do Serviço Civil, obrigados a desempenhar tarefas que aumentam, progressivamente, em volume e complexidade.

Não há atividade privada, individual ou de emprêsa, que não esteja sujeita a relações permanentes com alguma ou com várias repartições administrativas e que delas não dependa para seu normal funcionamento, seja para regularização e registro do seu status legal, seja para cumprimento e fiscalização das obrigações tributárias, seja para receber orientação ou assistência técnica. 
A desarticulação da engrenagem administrativa do Govêrno determina, pois, inevitàvelmente, o emperramento de tôdas as atividades úteis exercitadas no País.

A própria segurança do Estado está condicionada, em grande parte, à boa Administração Pública. As nações de estrutura política mais sólida e estável, sem agitações profundas que afetem o bem-estar e a tranqüilidade sociais, são as que dispõem de Serviço Público Civil competente e atuante.

Ora, não há como olvidar que a imensa máquina estatal é acionada pelo elemento humano que a ela se devota. Sem o Homem, todo sistema administrativo é massa inerte, amorfa, inoperante.

Dêsse modo, os problemas de pessoal na Administração Pública são, precípua e essencialmente, problemas de Estado.

Desconhecê-los, marginalizá-los, procrastinar sua solução, não representa, apenas, uma injustiça praticada contra o corpo de servidores públicos. É, principalmente, grave êrro de política administrativa, com reflexos nocivos e irreparáveis, cujos danos atingem tôda coletividade nacional.

Mas para que o Homem se dedique ao seu trabalho, para que se esforce, para que seja capaz de produzir, é indispensável que êle encontre, na sua carreira, incentivos reais, possibilidades de progresso social e econômico, condições que the proporcionem tranqüilidade de espírito, subsistência condigna, sentimento de realização e segurança.

Sem êsses elementos, o trabalhador de qualquer condição será sempre o indivíduo desalentado, descrente de sua própria ação, pois que não poderá ter entusiasmo nos serviços que executa em proveito alheio, quando sua atividade não the fornece os meios para atender às suas próprias e legítimas aspirações.

Os problemas do funcionalismo civil, entre nós, não têm sido encarados com o cuidado e a consideração que merecem. A indefinição da política governamental, no tocante ao pessoal civil, é notória. Medidas isoladas são adotadas, nem sempre com uniformidade em todos os setores da Administração. Muitas vêzes, enquanto providências restritivas são impostas, no tocante a direitos e vantagens, em alguns órgãos e ministérios, outras primam pela excessiva liberalidade. As modalidades de retribuição assumem as mais diferentes formas para não dizer que seguem os mais disfarçados processos, criando desigualdades de tratamento e ferindo os preceitos de eqüidade, o que é fator 
de geral descontentamento e de conseqüente desestímulo. Os critérios de remuneração são de manifesta irracionalidade, apurando-se verdadeiros contra-sensos, em detrimento da hierarquia natural das funções.

Por outro lado, a própria classe permanece, geralmente, em atonia e só se movimenta quando se torna insuportável a pressão do custo de vida.

Nessa oportunidade, surgem as reivindicações irresponsáveis e demagógicas, suscitadas pelos elementos desagregadores que não se interessam pelas soluções definitivas de alto sentido público e social, porque se esforçam, exatamente, para manter o corpo do funcionalismo civil em estado de permanente inconformismo e frustração; em choque com o Poder Público; em conflito com as demais classes sociais e com as próprias Fôrças Armadas, formando o caldo de cultura da subversão.

Exemplo frisante é o das periódicas campanhas pela paridade entre civis e militares, como se pudesse haver paridade entre situações nitidamente dessemelhantes.

O evidente propósito é o de estabelecer ambiente de hostilidade mútua, de luta de classes, de agitação social.

A perturbação dos serviços da Administração Pública (quanto mais não seja, pela revolta passiva dos servidores civis) já representa um êxito ponderável para os que trabalham pela implantação da desordem, como processo de demolição das instituições vigentes.

As campanhas que se lançam, nesses momentos, exploram a feição sentimental do problema, registram um tom lamuriante, como se os servidores públicos fôssem massa de desamparados que deve ser mantida e sustentada com o sacrifício do comércio, da indústria, dos profissionais liberais, da lavoura, desviando todos os recursos dos cofres públicos para o seu socorro.

Este é um quadro inteiramente falso. O que se faz necessário é compreender que sem o servidor civil em condições de atuar, com produtividade, é inevitável o sacrifício de todo o conjunto social. As atividades que propulsionam o avanço do País sofrem, sem exceção, pela falta de servidores aptos e capazes na Administração Pública.

Manter o funcionalismo civil em nível satisfatório de condiÇões de vida não é obra de benemerência ou filantropia, mas representa interêsse público relevante, vinculado às necessidades mais prementes do desenvolvimento nacional. 
Os aumentos salariais generalizados, em níveis cada vez mais afastados do ritmo de crescimento do custo de vida, não oferecem solução ao problema e têm, via de regra, efeitos contraproducentes, provocando desproporcionadas altas dos preços de tôdas utilidades e retardando a contenção do surto inflacionário.

O que se faz mister é o estabelecimento de uma política global de administração do pessoal, que enfrente corajosamente os problemas em seu conjunto e não se atenha a soluções c'e emergência, adotadas quase sempre com açodamento e sob pressões de tôda espécie.

São imprescindiveis e inadiáveis estudos sérios que tracem as linhas diretrizes de um programa estável, a ser executado, sem solução de continuidade, a longo prazo, e que tenham por finalidade não só a manutenção dos quadros de pessoal em clima de entusiasmo pelas atividades do serviço público, mas o recrutamento de elementos de categoria que rejuvenesçam êsses quadros e os tornem cada vez mais pujantes e dinâmicos.

Através dos diversos capítulos dêste trabalho, procuraremos demonstrar que o problema salarial no serviço público não comporta soluções isoladas, nem é resolvido a contento com aumentos percentuais indiscriminados que impõem severos e imediatos ônus ao Tesouro, dando resultados exíguos e decepcionantes e impedindo a distribuição mais equitativa e racional dos recursos públicos destinados ao pagamento de pessoal. Ao problema salarial acham-se vinculados vários outros, cuja solução permitirá condições não só muito mais equitativas, mas certamente menos dispendiosas e antieconômicas.

\section{I - PROVIMENTO DE CARGOS PÚBLICOS}

Quando se procura investigar a causa de certos aspectos negativos da Administração Pública brasileira, é comum apurarse que ela se origina, desconcertantemente, de medidas governamentais mal inspiradas que, em aparência, se destinavam a produzir efeitos frontalmente opostos aos que afinal se concretizam.

Assim é, por exemplo, o caso da hipertrofia do corpo de pessoal civil da União Federal que tantos males ocasiona, constituindo-se não só no óbice mais sério à erradicação do deficit orçamentário mas, também, no empecilho ao melhor aproveitamento dos créditos disponíveis para justa e compensadora remuneração do trabalho dos servidores públicos. 
Não temos qualquer dúvida em afirmar que o excesso de pessoal, observado, reconhecido e proclamado, que todos se esforçam por corrigir, resulta, exata e precisamente, da política de proibição de nomeações que se iniciou, há alguns anos, em governos de pouca autoridade e na qual se persiste, com palpável êrro de apreciação do problema.

E mister declarar, de logo, sem rebuços, que essa política foi encetada com mal disfarçados propósitos demagógicos, pois as regras de autolimitação estabelecidas não eram observadas pelos próprios governos que, ao instituí-las, visavam à valorização das constantes e inumeráveis exceções, abertas com base no ajustamento de interêsses quase sempre divorciados dos do serviço público.

Nos anos que precederam a Revolução de 1964, assistiase, freqüentemente, ao espetáculo de a expedição de decreto proibitivo de novas nomeações ter, como arautos, milhares de atos de provimento de cargos, nos órgãos centralizados e autárquicos, sem observância de qualquer processo seletivo, quer quanto à necessidade do preenchimento das vagas, quer quanto à habilitação dos candidatos favorecidos. Secretarias de Estado varavam as noites no afã de elaborar as "últimas" nomeações. Mas, nos dias subseqüentes e durante várias semanas, continuava o Diário Oficial pejado de decretos, todos, por notável coincidência, com datas próximas da véspera do ato restritivo.

Seguia-se, então, pequeno intervalo mas, pouco tempo depois, recrudescia o fluxo das nomeações, a título excepcional e desacompanhadas de justificação.

Tal orientação torna-se de certo modo compreensível quando emana de governos tíbios, sujeitos a injunções políticas subalternas.

Porém, num Govêrno em que há unidade de propósitos, coincidentes com o interêsse público e em que as normas traçadas pelo Poder superior se destinam a fiel e exato cumprimento, não se explicam, nem se justificam providências autolimitativas que vão desfalcando os efetivos permanentes das repartições do Estado e impedindo as unidades administrativas de bem cumprir suas funções específicas pela redução progressiva de sua lotação que deve ser fixada em função de necessidades comprovadas.

O prosseguimento dessa política não leva em conta alguns fatos básicos, de significativa importância. 
O primeiro dêles é que a falta de preenchimento das vagas nos quadros do serviço público importa, necessàriamente, no perecimento do preceito fundamental da seleção, pelo sistema do mérito.

Realmente, não tem sentido a abertura de concursos, cujo custo é sempre elevado, se o provimento de cargos, pelo processo democrático de demonstração pública de aptidões, está proibido.

A insistência na realização de concursos, sem cargos a preencher, é o que tem contribuído para esvaziar e desmoralizar todo o sistema de seleção, criando a situação insuportável que resulta da existência de dezenas de milhares de candidatos aprovados, em todo o País, os quais aguardam, indefinidamente, a nomeação conquistada em competição honesta. A prorrogação da validade dos concursos, dada por leis sucessivas, é uma burla de flagrante inutilidade e, quando se restaurar a normalidade do processo, produzirá efeitos contra-indicados, pois que virá forçar o aproveitamento de candidatos de conhecimentos desatualizados há longo tempo.

Bastará consultar os assentamentos do DASP, para que se verifique que há número elevadíssimo de candidatos aprovados em concursos, ainda vigentes, para as mais diversificadas funções públicas, esperando, há longos anos, a oportunidade de ingresso no serviço público.

Por outro lado, não consideram os que se atêm a uma prática desaconselhável, oriunda de governos condenados, à realidade das exigências do serviço.

Qualquer unidade tem atribuições definidas e para executá-las não prescinde de pessoal compatível, em número e qualificações, com o serviço a ser desempenhado. Um simples pelotão, uma companhia, um batalhão tem, cada um dêles, 0 seu efetivo, o seu contingente, indispensável à realização de sua missão peculiar.

Dêsse modo, não se pode compreender que à Administração Pública seja vedada a substituição dos elementos que se afastam por morte, aposentadoria, exoneração, nomeação ou transferência para outros cargos, isto sem mencionar as imposições que nascem do crescimento progressivo dos serviços.

Foi essa realidade, contingência iniludivel, aliada à proibição do preenchimento de vagas nos quadros permanentes, que levou a Administração Pública ao emprêgo de artifícios de tôda a sorte para admissões, encobertas sob os mais variados pro- 
cessos que desencadearam uma avalancha de nôvo pessoal, invadindo todos os setores do serviço público, sem contrôle efetivo, quer no tocante ao número, quer no tocante aos niveis salariais.

Sob a forma de contratados, de avulsos, de temporários, pagos por tarefa ou mediante recibo e até por "gratificações" de Gabinete e de todo tipo, utilizando-se verbas de natureza e destinação diferentes, verificou-se imensa infiltração no serviço público de massa incontável de empregados que vai permanecendo e caminhando para a estabilidade.

Dêsse modo, ao invés do preenchimento normal dos quadros de efetivos, preestabelecidos em função das reais necessidades de serviço, abriu-se ensejo ao arbítrio dos dirigentes de repartições públicas e de órgãos autárquicos para o empreguismo desenfreado.

Essa a razão primordial, senão única, da pletora de pessoal atualmente verificada no serviço público e dos descomensurados gastos conseqüentes.

Acontece, ainda, que, nas ocasiões dos reajustamentos gerais de vencimentos, êsses servidores de tôda natureza, cuja admissão é geralmente feita com salários mais atualizados, recebem aumento igual ao concedido aos demais funcionários efetivos. É êsse um outro fator de injustiça e de desestímulo, porque os funcionários mais antigos, não poucos nomeados por concurso, e com longo tempo de serviço, assistem, constantemente, ao ingresso de privilegiados, sem qualquer demonstração prévia de competência e cujos salários, logo de início mais elevados, vão-se distanciando, em progressão acelerada, dos níveis de retribuição do pessoal permanente, mercê de aumentos percentuais, aplicados indistintamente.

Não se diga que esta é uma situação irregular e anômala que pertence ao passado. A verdade é que, até recente data, prosseguiam, em ritmo bastante sensível, as admissões de pessoal variável de tôdas as denominações.

Vão assim crescendo, como cogumelos, à margem dos quadros permanentes, tabelas de pessoal instável, movediço, sem condições de oferecer trabalho seguro e produtivo.

Esse imenso contingente humano só tem um objetivo comum, um "goal" certo que lhe dá unidade de propósitos e lhe atribui fôrça para agir como massa de pressão sôbre o próprio Poder Público: - é a aspiração natural de segurança de emprêgo, a obtenção de cargo com estabilidade, na Administração. 
Êsse objetivo tem sido alcançado, com sucesso, através de leis de efetivação, consagradas e ratificadas por disposições insertas nos próprios textos constitucionais.

Ao ignorar êsse problema, deixando de the dar solução racional e definitiva, o Estado deixa de lado, também, um dever imperioso.

É que mesmo a pequena emprêsa privada, ao lado dos seus objetivos especificos, tem um encargo social a que não pode fugir: o de abrir oportunidade de emprêgo, em condições sadias, às novas gerações.

A Administração Pública, a mais complexa das emprêsas, que utiliza tôdas as atividades, das mais singelas às de maior porte técnico, profissional e científico, não pode eximir-se da obrigação de franquear suas portas ao ingresso, por processos dignos e democráticos, dos jovens que atinjam a idade de trabalho útil e tenham inclinação para o serviço público.

Se assim não agir, ficará a Administração sem meios para promover o rejuvenescimento dos seus quadros e o recrutamento incessante dos elementos aptos e eficientes de que carece.

A renovação é de necessidade inquestionável e, no caso da Administração Pública federal, a própria reestruturação dos seus quadros é urgente.

Êles apresentam, sem exagêro, uma situação verdadeiramente caótica, em parte decorrente das infiltrações já mencionadas e, também, em resultado de efetivações em massa, de readaptações, de alterações de cargos feitas sem qualquer sistemática e até provenientes de sentenças judiciárias que, prêsas a fórmulas jurídicas, não consideraram qualquer aspecto de conveniência administrativa.

Temos absoluta convicção de que serão inúteis quaisquer medidas restritivas, por mais enérgicas e moralizadoras que sejam, se não forem simultâneamente contemplados os imperativos do serviço da Administração. Tais providências isoladas tornar-se-ão inoperantes se não forem imediatamente seguidas de estudos sérios e demorados de tôdas as implicações dos problemas de organização dos quadros de pessoal do serviço público civil.

Inevitàvelmente, serão forçadas, em breve, soluções de emergência, tão a gôsto de alguns dirigentes e de seus conhecidos pruridos de autonomia. 
Sob a capa de necessidades demonstráveis, retomar-se-á, dentro em pouco, o processo de admissões sem contrôle, sob disfarces de tôda a sorte, em que é sempre fértil a inventiva oficial.

Ao lado, pois, das medidas fortes e saneadoras, no sentido de impedimento transitório de novas admissões, é imprescindivel que a Revolução não perca a oportunidade ímpar de organizar, racionalmente, os quadros do funcionalismo civil, fixando-lhe os efetivos e restabelecendo o processo normal e legal de criação de cargos permanentes e de seu provimento.

Nas conclusões finais dêste trabalho, é apresentada uma série de sugestões de ordem prática, para execução dessa tarefa fundamental cujos frutos serão, não sòmente, a estruturação de quadros que ofereçam ao funcionalismo estável, selecionado em provas públicas, um horizonte de progresso funcional e de aprimoramento constante, mas ainda a discilpina da despesa pública e, de certo, não pequena economia, pelo efetivo contrôle dos gastos de pessoal.

\section{II - SISTEMA DE RETRIBUICCÃO \\ DO TRABALHO NO SERVIÇO PÚBLICO CIVIL E PROBLEMAS CORRELATOS}

Dispensa qualquer demonstração a evidência de que os reajustamentos periódicos de vencimentos e salários dos servidores públicos civis impõem sacrifício extremamente árduo ao Tesouro Nacional, sem corrigir os múltiplos defeitos do sistema de retribuição da classe, nem atender aos interêsses da Administração.

A considerável elevação da despesa pública que êles determinam força a concessão de percentagem de aumento sempre insatisfatória e causa permanente de geral descontentamento e frustração, hàbilmente explorada pelos que se devotam à tarefa de incompatibilizar o Govêrno com o funcionalismo, com o escopo de perturbação dos serviços do Estado.

A percentagem uniforme de aumento aplica-se a vencimentos e salários reconhecidamente desajustados que não correspondem, em grande número de casos, à média vigorante no mercado de trabalho, verificando-se ora excessos, ora diferenças sensiveis em sentido contrário. Desta forma persistem e até se agravam desigualdades de tratamento e distorções, identificadas há longo tempo, não raro no âmbito de uma mesma repartição.

A eliminação dessas disparidades de nocivo efeito é, entretanto, postergada indefinidamente. 
O próprio vulto do encargo mal suportado pelo Erário, nos sucessivos aumentos gerais, é fator que contribui para o adiamento de soluções definitivas, pelo receio de que venham desencadear outros pesados ônus suplementares.

É manifesta, contudo, a necessidade de serem encontradas fórmulas que, sem sobrecarregar ainda mais os cofres públicos, possam encaminhar medidas capazes de, gradual e progressivamente, erradicar os graves erros do sistema de retribuição dos servidores do Estado e que sejam, ao mesmo tempo, instrumento eficaz de incentivo aos funcionários competentes, dedicados e produtivos, habilitando, também, a Administração Pública a pagar salários compativeis com a alta responsabilidade e qualificação técnica de certos cargos, dos quais vão desertando os elementos de melhor categoria, quando nêles não se afincam apenas para receber o vencimento e fazer jus à aposentadoria, entregando-se, porém, a outras atividades estranhas mais compensadoras.

Reconhece-se inviável a concessão de aumentos discriminatórios pelas reações naturais que provocam.

Entretanto, há distinções nítidas que podem e devem ser estabelecidas, num regime de eqüidade, compatível com a conveniência da Administração.

O primeiro e natural processo de estímulo ao mérito e à produtividade é o avanço na carreira funcional através da pro. moção e do acesso a outras carreiras de nível superior. Esse é um método legítimo de distinção que por todos os motivos se recomenda e ao qual nada se opõe.

No entanto, o sistema de promoções no Serviço Público Civil é, certamente, o ponto mais falho de todo o regime da Administração de Pessoal. Custoso, lento, altamente burocratizado, êle se manteve nos últimos 8 anos em estado de estagnação indisfarçável .

Merecem louvor os esforços do DASP e dos órgãos de pessoal dos diversos Ministérios, no sentido de atualizar as promoções, inclusive as de antigüidade, que permaneceram paralisadas por vários anos.

O processamento dos acessos sofreu também um impulso que o veio colocar na primeira fase de funcionamento, graças à iniciativa do setor competente do DASP, no sentido de realizar as provas de habilitação correspondentes.

A verdade, todavia, é que sem a alteração radical do processo jamais será possível ativar, ou mesmo manter em ritmo 
regular, as promoções e os acessos nos quadros do funcionalismo civil.

No regime vigente as promoções realmente ficarão adstritas ao critério da antigüidade, relegado ao abandono o fator essencial do merecimento.

O progresso funcional, no tocante à elevação de salários, não considerados os reajustes gerais, impostos pela desvalorização da moeda, limita-se, quase que exclusivamente, à automática incorporação de gratificações qüinqüenais, por tempo de serviço, e às promoções por antigüidade, estas sempre feitas com imenso atraso.

A apuração do merecimento, objeto de intenso e volumoso trabalho burocrático, falha redondamente porque foi subordinada a um processo de julgamento que termina pela quase que sistemática atribuição de pontos máximos a todos os funcionários indistintamente, daí resultando o desempate pelo critério de antigüidade. Isto decorre, em grande parte, da constituição dos descomunais Quadros únicos que dificultam a apreciação mais próxima e direta do mérito de cada funcionário, salvo pelo seu chefe imediato. Daí uma multidão de funcionários concorrendo às mesmas vagas e sujeito cada qual aos critérios de julgamento de um chefe diferente.

O temor de praticar injustiça em detrimento de seus subordinados diretos que vão competir com outros colegas em grande número, talvez de menor merecimento, mas sob chefias mais condescendentes, conduziu à solução de menor esfôrço que é a generalização das notas máximas, como regra quase sem exceções.

A apuração do merecimento pelo processo atual é reconhecida por todos os que conhecem o problema como completa inutilidade que, não obstante, determina gastos substanciais de papel, de tempo, de emprêgo de contingente elevado de servidores em todos os órgãos de pessoal, num esfôrço improfícuo.

Saliente-se, todavia, as repercussões negativas dêsse formal abandono de um dos aspetos fundamentais do sistema do mérito, no Serviço Público Civil.

Por outro lado, a disciplina, o respeito aos horários de trabaIho, a assiduidade, o zêlo e a dedicação no exercício da função pública perderam o sentido desde que não têm influência decisiva no sistema de promoções.

Finalmente, a péssima classificação de cargos pràticamente aboliu as carreiras funcionais e não só veio emparedar o 
servidor público, pelas reduzidíssimas perspectivas de avanço, como contribui para abalar o princípio da hierarquia e da valorização dos postos superiores.

É que as séries funcionais se resumem a 2 ou 3 classes. $O$ funcionário mal ingressa no serviço público e fica a poucos passos do ápice de sua carreira.

De todo o exposto, conclui-se que a reformulação do sistema de promoção e de acesso, como meio de incentivo ao mérito é um dos itens principais de um programa de Administração de Pessoal, tornando-se imprescindivel, contudo, promover a reclassificação de cargos, para constituição de carreiras funcionais que ofereçam amplas perspectivas de progresso e restabeleçam a hierarquia no Serviço Civil.

Com êsse objetivo são formuladas propostas concretas nas conclusões dêste trabalho.

Outra providência de profunda significação e não menos urgente é um estudo completo, com vistas à reavaliação dos níveis de vencimento de cargos, em função dos respectivos encargos, nível de conhecimentos exigidos para seu desempenho, complexidade e responsabilidade das atribuições correspondentes e condições do mercado de trabalho.

O exame detido do assunto é de importância fundamental e exige pesquisas demoradas que não podem ser realizadas com proveito, sob pressões, nem açodamento.

A tarefa é difícil mas plenamente realizável e para comprová-lo basta invocar o exemplo do Estado da Guanabara que dispõe de Quadro bastante numeroso de pessoal permanente e realizou êsse trabalho com sucesso e resultados amplamente compensadores.

A disciplina do sistema salarial; o perfeito contrôle da despesa pública com o pessoal; a abolição de privilégios; a correção de injustiças clamorosas; a possibilidade de a Administração contar com elementos aptos e de categoria para 0 exercício de funções especializadas, técnicas e científicas e todo um outro cortejo de soluções de magna relevância dependem, exclusivamente, da cuidadosa reavalização dos níveis de vencimentos dos cargos públicos civis.

A análise do sistema vigente revelará aspectos imprevistos, além dos que já são de muito conhecidos e que, por si próprios, justificam, senão reclamam, que êsse trabalho seja encetado, sem demora. 
Verificar-se-á, por exemplo, que, em não pequeno número de casos, a providência a tomar não será a elevação de vencimentos, mas a drástica redução de vantagens desproporcionadas que originam descontentamentos gerais e muito concorrem para estabelecer, no âmbito de certas repartições, um clima de hostilidade e despeito entre seus servidores, uns com regalias excepcionais, outros pèssimamente remunerados, tudo com reflexos detrimentosos à harmonia e à normalidade dos serviços.

A reavaliação dos níveis de vencimentos dos cargos públicos, para o estabelecimento de justos padrões, não importa, necessàriamente, em elevação automática e imediata de despesa, por isso que a aplicação individual dos novos índices pode ser desdobrada em etapas e condicionada, outrossim, à prestação de provas, à conclusão de cursos de especialização e a outras exigências prescritas em lei ou regulamento.

Dêsse modo, os funcionários, estimulados pela possibilidade de melhoria de vencimento, empenhar-se-ão em satisfazer as condições de habilitação estatuídas em cada caso. E os que não as preencherem, por desinterêsse ou incapacidade, permanecerão nos niveis anteriores.

Outro lídimo processo de retribuir em função da produtividade de cada um, dando-se mais àqueles que por sua vez mais dão ao serviço público, é o do regime de tempo integral.

A correta execução do sistema, que tem sido na prática bastante desvirtuado, poderá transformá-lo em instrumento decisivo para melhoria das condições gerais de eficiência do serviço público, propiciando, inclusive, a redução de quadros, medida desejável sob todos os aspectos.

O baixo nível de vencimentos, aliado à pletora do funcionalismo, conduziu a Administração ao panorama atual em que uma percentagem muito elevada de servidores do Estado exer$\mathrm{ce}$, em caráter particular, duas ou mais atividades paralelas, para suprir a deficiência do seu orçamento doméstico.

Torna-se inevitável que a atenção maior seja dispensada às ocupações mais compensadoras, relegando-se, quase sempre, a segundo plano, as do serviço público.

O reconhecimento de situações pessoais verdadeiramente aflitivas e o invencível pendor, muito brasileiro, para tolerância, levada até ao exagêro, através do sacrifício do cumprimento do dever, fazem com que muitos chefes de serviço fechem os olhos a horários e à assiduidade, admitindo certos ajustamentos de interêsses, nem sempre compatíveis com os da Administração ou com a Lei. 
Não é incomum encontrar, em certas repartições, funcionários que exercem variado comércio, no próprio recinto de trabalho e entre colegas, desviando grande parte da atenção e do tempo a que faz jus o serviço público.

Esta é uma realidade inegável que tende a generalizar-se.

O restabelecimento da profissionalização da carreira pública, mediante ampliação progressiva do regime de tempo integral e dedicação exclusiva à Administração, constitui imperativo, de prioridade essencial.

Para que o regime não se desmoralize, conformando-se a um disfarçado aumento salarial de protegidos, far-se-á preciso que êle funcione sob fiscalização severa, sistemática e eficaz. Essa fiscalização é perfeitamente exeqüivel e pode ser implantada e posta em execução, sem dificuldades maiores. Ela deverá contemplar não sòmente o comparecimento dos funcionários submetidos ao tempo integral e a sua permanência nos horários estabelecidos mas, e principalmente, o resultado do seu trabalho, o incremento da produção da equipe e a fiel observância do preceito vedativo do exercício de outras atividades marginais que, na prática, vêm suplantando a função pública até colocá-la na posição de simples "bico" suplementar.

Se o funcionalismo sentir que a dedicação exclusiva à Administração Pública realmente compensa, ter-se-á dado grande passo no sentido da normalização dos serviços do Estado.

Mas se a medida assumir aspectos de favoritismo ter-se-á, apenas, acrescentado, a tantos outros, um nôvo fator de descrença e de desestímulo.

Outros incentivos de que urge cogitar-se são a gratificação de produtividade e a correspondente ao exercício em certas zonas do território nacional de maior desconfôrto ou dificuldade de vida ou em locais de condições penosas para o trabalho.

A primeira oferece certas dificuldades de regulamentação que, entretanto, são removiveis. O certo, porém, é que em qualquer emprêsa o rendimento do trabalho deve ser o fator básico da remuneração.

Quanto à segunda, parece inquestionável a necessidade de criar condições realisticas que permitam a movimentação de pessoal, levando a todos os recantos do País elementos categorizados e eficientes que hoje se radicam nos poucos centros mais adiantados por falta de estímulos e, especialmente, de condições econômicas suportáveis. 
Todo êsse conjunto de medidas visa a um programa global que assegure ao funcionário retribuição proporcional ao seu esfôrço, à sua capacidade, à sua utilidade para a Administração, suprimindo generalizações que não distinguem o mérito e, por isso mesmo, deixam de ser eqüitativas.

Dentro dêsse plano, cumpre encarar, com coragem e decisão, todo o sistema de gratificações e vantagens, para abolição definitiva de concessões abusivas de todo tipo, que se fazem sob as mais diferentes capas, sem apoio legal e com utilização de recursos impróprios, ocultando o real montante das despesas de pessoal, instituindo o nepotismo e consolidando disparidades de retribuição, em função de órgãos privilegiados e da prodigalidade de seus dirigentes.

A unidade do sistema de retribuição do servidor público é essencial. Nenhuma vantagem, não prevista e autorizada por lei ou sob condições diferentes das que nela são estabelecidas, pode e deve ser paga.

O rigor na fiscalização da observância dêsse princípio básico deve ser inflexível.

Temos a absoluta certeza de que se a Revolução se valer da oportunidade excepcional que as circunstâncias the facultam, para impor a moralização no tocante a pagamentos a pessoal, haverá substancial economia e melhor emprêgo dos dinheiros públicos, cessando, ao mesmo tempo, regalias injustificadas que não trazem qualquer benefício à Administração e, ao contrário, pela injustiça que representam, formam um ambiente geral de inconformismo e desânimo entre os servidores públicos civis.

Dentre os problemas que reclamam providências inadiáveis está o das acumulações remuneradas.

Ninguém ignora neste País que persiste, impunemente, a situação de muitos milhares de servidores que acumulam não 2 , mas 3 ou mais empregos públicos, desafiando, impunemente, a vedação constitucional.

O ajustamento de horários, quando êstes são respeitados, é feito ao sabor da conveniência do funcionário, ainda que com prejuízo do exercício normal do serviço. Em muitíssimos casos, além da transgressão dos preceitos proibitivos, há incontornável impossibilidade material do desempenho simultâneo dos diversos cargos.

O contrôle atual dessas situações altamente irregulares é pràticamente nulo. Por outro lado, a Constituição não prima pela 
excelência neste particular. A exceção aberta para os médicos, por exemplo, só contribui para estimular a concentração, cada vez mais forte, dêsses profissionais nos grandes centros, onde há possibilidades mais largas de empregos públicos privativos, abandonando o interior, onde seus serviços são requeridos, por necessidade pública mais premente.

A Constituição não deveria conter preceitos discriminatórios, em favor de determinada profissão. Outrossim, a rigidez da norma não se afigura indicada em texto constitucional que deve assumir flexibilidade adaptável às imposições do interêsse público, em face de situações mutáveis.

É bem possivel, por exemplo, que circunstâncias eventuais tornem conveniente ampliar o recrutamento no serviço público, não só de médicos, mas de engenheiros, de veterinários, de agrônomos, de farmacêuticos, de químicos ou de quaisquer outros técnicos ou profissionais de que haja carência, seja em todo País, seja em determinada região.

O lógico e racional, portanto, seria que a Constituição reservasse à lei ordinária fixar as condições em que seria permitida, em caráter transitório ou permanente, no País ou em certa faixa territorial, a acumulação de 2 cargos técnicos ou científicos, da administração centralizada ou da autárquica, verificadas, sempre, a compatibilidade de horário, a correlação das funções e a conveniência da Administração.

Nessa conformidade poderiam ser atendidas, no tempo $e$ no espaço, sem desrespeito ao mandamento fundamental e de acôrdo com as necessidades observadas, as situações de acumulação permitida por fôrça de interêsse público relevante.

Em qualquer hipótese o que não é possivel admitir é a indiferença e a passividade, em face de frontal e inequívoca transgressão das normas constitucionais e legais, perpetrada com evidente dano do serviço público e para assegurar posições de privilégio ilegítimo.

Nesse trabalho são propostas medidas tendentes a pôr têrmo definitivo a êsse irregularíssimo aspecto da inércia administrativa, em face do abuso e da caracterizada infração das Leis do País.

Finalmente, qualquer programa de administração de pessoal não pode deixar de incluir dois itens de importância fundamental, a saber:

a) revisão do Estatuto dos Funcionários para sua atualização, correção de impropriedades graves e restabelecimento da unidade do regime jurídico do pessoal civil; 
b) prestígio do órgão central do sistema de pessoal (DASP) para revitalizá-lo, mantendo-o na posição de que não pode prescindir para que fique habilitado a dar exato cumprimento à alta função que a Lei lhe confere.

No tocante ao Estatuto dos Funcionários a ocasião é única para consolidação de um diploma em que direitos e vantagens tenham como obrigatória contrapartida deveres e responsabilidades.

O atual Estatuto, por seus inúmeros defeitos, não é instrumento adequado de administração moderna e dinâmica. Os processos de definição de responsabilidades e de ação disciplinar são pràticamente inoperantes e reclamam normas mais eficazes e de execução fácil e pronta.

Por outro lado, a falta de disposições firmes e precisas sôbre direitos e vantagens abrem brechas através das quais se infiltra uma variedade infinita de extensões descabidas, facultando concessões injustificáveis e tornando inexeqüível um contrôle efetivo.

A dualidade do sistema legal dos servidores civis também é fonte de múltiplos inconvenientes.

Em geral, os que se inclinam pela aplicação do regime da Consolidação das Leis do Trabalho a faixas cada vez mais largas de servidores do Estado, visam à redução de garantias excessivas que, aparentemente, prejudicam a flexibilidade da ação administrativa. Essa conclusão decorre de exame superficial do problema.

$\mathrm{Na}$ verdade, a legislação trabalhista assegurou ao empregado direitos e faculdades que, em muitos casos, constituem empecilhos muito sérios para a Administração Pública. Paralelamente, concede favores de que não goza o funcionalismo permanente, como o 13 ? salário, Fundo de Garantia e outros, cuja generalização, no serviço público, cria problemas de solução bastante onerosa.

Demais disso, com a dualidade do regime jurídico dos servidores do Estado, abdica o Poder Executivo, em relação a grande massa de empregados, à uniformidade do exercício do poder disciplinar, transferindo à Justiça do Trabalho ou à Justiça comum a apreciação e a decisão de dissídios que, normalmente, seriam dirimidos no seio da Administração e, sòmente por exceção, submetidos ao Judiciário.

Será inevitàvelmente afetada a disciplina do serviço público se a ação disciplinar administrativa ficar sujeita à constante variação de interpretação de sucessivas instâncias judiciais. 
O que se faz mister é a completa reformulação do regime estatutário do servidor civil, a fim de que, mantida a unidade geral do sistema, sejam estabelecidas normas próprias e diferenciadas para reger o pessoal essencialmente variável, incumbido de tarefas eventuais e transitórias.

Quanto à direção geral do sistema de pessoal é evidente que, realizada isoladamente através de medidas dos Ministérios, tornará inviável o exato cumprimento das diretrizes fixadas, pelo natural conflito entre órgãos de igual hierarquia e pelas inevitáveis implicações políticas daí oriundas.

É imprescindível que o órgão central do sistema atue sob inspiração eminentemente técnica, afastado das competições ministeriais. Sem sofrer as influências e pressões dos interêsses pessoais mais próximos da direção de repartições ministeriais e das entidades autárquicas, êle estará apto a agir, no plano técnico, no assessoramento direto ao Presidente da República. Seus estudos, pareceres, conclusões, propostas, serão submetidos ao Chefe de Estado, visando à consolidação de normas uniformes e impessoais. Quando aprovados, êsses trabalhos consagrarão diretivas emanadas da Autoridade Suprema, de aplicação geral obrigatória e que não poderão gerar oposições.

São fàcilmente compreensiveis as dificuldades levantadas em qualquer dos Ministérios na execução de ordens ou instruções provenientes de órgão subordinado a outro Ministério.

Rivalidades insuperáveis, espírito de competição política, conflito de jurisdições, tornam-se conseqüências inarredáveis.

Não se reivindica para o DASP uma autoridade em plano superior ao de tôda a administração centralizada ou autárquica. Ao inverso, o que se pretende, exatamente, é afastá-lo de qualquer terreno em que se verifique atrito de autoridade, para darIhe posição de inteira autonomia técnica na apreciação serena dos problemas de pessoal, orientado no sentido de soluções de conjunto. Sua função precípua será de opinamento e de formulação de propostas. Sòmente após a homologação superior, de autoridade incontrastável, êle agirá no sentido do disciplinamento da execução em todos os setores, indistintamente.

Sem a restauração dêsses alicerces do sistema, o DASP permanecerá sujeito às flutuações de critérios e à diversidade dos processos de aplicação dos preceitos normativos, num descontrôle que abala tôda a estrutura e consagra desigualdades de regime do pessoal na Administração Pública, fomentando reivindicações inatendíveis e criando um sentimento generalizado de inconformidade contra a falta de eqüidade e justiça. 


\section{III - PROPOSTAS OBJETIVAS}

PARA EXECUÇÃO A LONGO PRAZO DE UM PROGRAMA DE ADMINISTRAÇÃO DE PESSOAL

1 - Estudo, em profundidade, a ser imediatamente iniciado, da lotação dos órgãos da Administração civil federal em razão das necessidades reais de cada um, como base para formação dos quadros permanentes. Cumprimento do disposto no artigo 98 da Lei de Reforma Administrativa (Decreto-lei $n$ ? 200 de 25-2-67).

1.1 - Êsse estudo deverá ser encetado, simultâneamente, em todos os órgãos ministeriais e autárquicos, onde há maior concentração de pessoal (Guanabara e Distrito Federal), estendendo-se, progressivamente, às demais unidades federativas em que tem exercício funcionalismo da Administração federal, com observância do mesmo critério de prioridade.

1.2 - O trabalho terá por base formulários, organizados pelo DASP, a serem preenchidos pelos chefes das unidades administrativas e revistos pelos dirigentes dos órgãos imediatamente superiores.

1.3 - Os formulários preenchidos pelos chefes de serviços e repartições conterão indicação precisa do número total de servidores em exercício, especificando as quantidades realmente empregadas no desempenho de cada atividade e apontando (de forma numérica, sem individualização) os desvios de funções impostas por necessidade imperiosa, os excessos de determinados cargos e a falta de outros, com justificativa minuciosa de qualquer ampliação pleiteada. O número de ociosos, por incapacidade ou inadaptação às funções, deverá ser, obrigatòriamente, indicado.

1.4 - Serão constituídos, em todos os ministérios e órórgãos da administração indireta, Grupos de Trabalho para análise dos formulários, mediante observação in loco, sempre que possivel, das exigências do serviço e das propostas de fixação do número de pessoal, a ser distribuído para o exercício das diferentes funções.

1.5 - O DASP organizará e porá em funcionamento cursos rápidos e intensivos de especialização sôbre análise de funções e princípios básicos de fixação de lotação. 
1.6 - Os ministérios e órgãos de administração indireta promoverão, ex officio, inscrições de servidores nesses cursos e, ao fim de período predeterminado, sòmente poderão participar dos Grupos de Trabalho os que hajam sido nos mesmos habilitados.

1.7 - Em todos os ministérios ou órgãos da Administração indireta em que o maior contingente de pessoal exigir a constituição de mais de um Grupo de Trabalho, haverá um Grupo Supervisor Central, incumbido da coordenação dos trabalhos, com vistas à garantia da unidade de critérios.

1.8 - As lotações das diferentes unidades administrativas poderão ser fixadas separadamente, visando porém à fixação de quadros departamentais, abrangendo setores amplos de atividades congêneres.

1.9 - As lotações serão aprovadas por decreto executivo depois de examinadas as propostas pelo DASP e mediante parecer do Conselho Federal de Administração de Pessoal.

1.10 - Das lotações serão excluídas as funções eminentemente transitórias, a serem exercidas pelo regime de tarefa, com prazo determinado improrrogável, por pessoal variável sujeito a regime legal próprio. Para execução dêsses trabalhos, sempre que possível, a Administração dará preferência à contratação da prestação do serviço em globo, por emprêsas privadas idôneas, evitando a admissão de pessoal.

2 - Provimento de cargos públicos - Seleção - Recrutamento.

2.1 - As proibições constantes da legislação em vigor terão caráter transitório, podendo entretanto ser prorrogada a sua vigência que ficará condiciona$\mathrm{da}$, em qualquer caso, à conclusão dos trabalhos de fixação das lotações e à constituição dos quadros permanentes, setoriais ou de âmbito ministerial.

2.2 - Fixados os efetivos de cada órgão do serviço público, em função de suas reais necessidades, promover-se-á o preenchimento das vagas que no mesmo ocorrerem. 
2.3 - O DASP incentivará o processo de recrutamento de pessoal de modo a dispor, com presteza, de elementos selecionados em provas públicas, para abastecer os órgãos da Administração à medida que ocorrer vacância.

2.4 - Os concursos terão caráter objetivo, guardando, nos seus programas e na extensão e profundidade das matérias exigidas, próxima relação com as funções a serem exercitadas, sem esquecer que o concurso é meio e o recrutamento é o fim a ser alcançado e que o candidato com excessiva habilitação torna-se, geralmente, elemento inadaptado às atribuições mais simples que seja forçado a desempenhar e de utilidade reduzida.

2.5 - Em complemento às disposições vigentes sôbre admissão de pessoal, o Govêrno expedirá instruções rigorosas, determinando a todos os órgãos da Administração o relacionamento completo do pessoal que mantém a seu serviço, pago sob qualquer forma ou processo, inclusive por verbas destinadas a gratificações ou a outras despesas, e estabelecendo a responsabilidade pessoal do chefe de serviço que ordenar pagamento que importe em admissão de pessoal a qualquer título.

3 - Sistema de promoções e de acesso.

3.1 - Revisão urgente do sistema de classificação de cargos para reconstituição de carreiras funcionais, com amplas perspectivas de progresso.

3.2 - A promoção deverá significar, obrigatòriamente, na atribuição de encargos de maior responsabilidade, para restauração da hierarquia no serviço civil.

3.3 - Substituição progressiva dos Quadros Únicos, pelos quadros setoriais ou departamentais mais reduzidos que permitam observação mais próxima do merecimento individual.

3.4 - Constituição, em cada Ministério, de uma ou de várias Comissões de Promoções, constituídas de funcionários das classes finais das carreiras. No caso de mais de uma comissão, no mesmo Ministério, a cada uma delas será atribuído o encargo de apreciação do merecimento de funcionários de uma ou de várias carreiras determinadas, assegu- 
rando-se, sempre, a unidade de critério de julgamento do grupo de funcionários concorrentes às mesmas promoções.

3.5 - Simplificação do sistema de apuração de merecimento que consistirá em informações objetivas dos chefes de serviço imediatos sôbre o gênero e natureza do trabalho executado pelo funcionário e forma e qualidade do desempenho.

3.6 - Reconhecimento da faculdade ao funcionário de fornecer às Comissões de Promoções, com visto do seu chefe imediato, documentação sôbre trabalhos realizados.

3.7 - Caberá à Comissão de Promoção organizar os quadros de promoção por merecimento que vigorarão pelo menos durante um exercício e poderão ter sua vigência prorrogada.

3.8 - Verificada vaga a ser preenchida mediante promoção, pelo critério de merecimento, os órgãos de pessoal organizarão, imediatamente, 0 ato respectivo que vigorará a partir de 30 dias da data da vaga.

3.9 - Os funcionários serão classificados, no Quadro de Promoções por merecimento, por ordem de pontos atribuídos pela Comissão de Promoções, de acôrdo com escala estabelecida em regulamento.

3.10 - Serão restabelecidas as condições fundamentais de merecimento (pontualidade, assiduidade e disciplina) cuja falta determina a contagem de pontos negativos e decesso no Quadro de Promoções, de acôrdo com escala estabelecida no Regulamento.

3.11 - 0 órgão de pessoal terá atribuição de alterar 0 quadro de merecimento, para decesso, pela perda de pontos correspondentes às condições fundamentais, quando o funcionário sofrer punição disciplinar, faltar injustificadamente ao serviço, retardar-se na entrada ou retirar-se, sem autorização, do trabalho. Dessa forma, todo o corpo de funcionários passará a ter direto e legítimo interêsse na freqüência ao trabalho e no cumprimento dos seus horários, cooperando na fiscalização. 
3.12 - Facilitação do processo de apuração de antigüidade pelos órgãos de pessoal que deve ser mantido rigorosamente em dia, retroagindo sempre os efeitos do ato a 30 dias após a ocorrência da vaga.

3.13 - Impulsionamento na realização de cursos e provas para acesso a carreiras de nível superior.

4 - Sistema de retribuição no serviço público civil.

4.1 - Início de estudo prioritário tendente à reavaliação dos níveis de vencimentos e salários, em função das atribuições a desempenhar, levando-se em conta a experiência e o nível educacional exigidos para o seu exercício, os encargos, deveres e responsabilidade que êste acarreta e as condições do mercado de trabalho.

4.2 - Estabelecimento de critérios para ajustamento progressivo aos novos níveis, mediante condições especiais de habilitação que se tornarem indicadas e/ou estabelecimento de interstícios de efetivo exercício, a fim de evitar-se o crescimento imediato da despesa.

4.3 - Revisão urgente dos regimes de remuneração especial, apurando-se, exatamente, o montante das retribuições pagas a determinados grupos de funcionários, mediante recomendação severa de prestação de informações exatas pelos órgãos pagadores.

4.4 - Supressão progressiva, com respeito aos direitos adquiridos, dos sistemas de retribuição especial que não correspondam a necessidade imperiosa e comprovada do serviço público e se revelem excessivos ou privilegiados.

4.5 - Ampliação do regime de tempo integral que deverá abranger tôdas as categorias de servidores e, paulatinamente, constituir a regra do serviço público civil, obrigando o funcionalismo do Estado à dedicação exclusiva, sem atividades paralelas, salvo poucas exceções. Essa ampliação deve ser graduada em função da redução de quadros.

4.6 - Enquanto não fôr obtido o resultado do item anterior, condicionar a ampliação do tempo integral à apuração rigorosa das necessidades e conveni- 
ências da Administração, não só mediante o exame prévio e cuidadoso das propostas dos órgãos interessados, mas através da fiscalização constante e sistemática do funcionamento do regime.

4.7 - Organização do sistema de fiscalização, mediante o recrutamento de funcionários selecionados que não estejam no regime de tempo integral nos respectivos órgãos de lotação, mas fiquem nêles incluídos, por intermédio do órgão incumbido do contrôle do sistema, no qual darão as horas extras de trabalho, cumprindo um programa de inspeção que êste organizará, em caráter reservado, compreendendo visitas repetidas e incertas aos diversos órgãos do serviço público e sob rodízio dos agentes de fiscalização. O simples início do sistema repercutirá imediatamente em todos os setores, coibindo abusos.

4.8 - Aplicação inflexível das sanções previstas na legislação não só aos funcionários que transgredirem o regime, mas aos chefes de serviço complacentes na sua execução ou que o pleitearem com extensão não proporcional às necessidades de serviço.

4.9 - Levantamento urgente, através do DASP, de tôdas as gratificações, bonificações ou vantagens que estejam sendo pagas a qualquer título, pelos órgãos do serviço público, além do vencimento e salário,' excluídas apenas as de caráter nitidamente eventual (como as ajudas de custo e as diárias por período determinado, nos casos de serviços fora da sede).

4.10 - Obrigatoriedade de fornecimento de informações completas e exatas dêsses pagamentos, sob pena de responsabilidade pessoal de quem as estiver recebendo e da autoridade que houver ordenado a despesa.

4.11 - Abolição imediata, por proposta do DASP, aprovada pelo Presidente da República, de quaisquer vantagens que estejam sendo irregularmente concedidas, sem prejuízo da responsabilização do beneficiário e da autoridade que houver feito a concessão, nos casos de ilegalidade demonstrada. 
4.12 - Reaparelhamento urgente do órgão incumbido do contrôle de Acumulação de Cargos, dando-lhe organização e estrutura que o tornem apto não só a responder consultas, mas a apurar e coibir as transgressões dos preceitos que regem a matéria.

4.13 - Expedição de Decreto que obrigue a todo servidor, que receba a qualquer título pagamentos de 2 ou mais órgãos da Administração Pública direta ou indireta, a comunicar, em prazo curto, fixado no Decreto, os pagamentos que em seu favor estejam sendo efetuados, indicando os órgãos pagadores, as quantias percebidas e a natureza e fundamento legal do recebimento.

4.14 - Estabelecer que a falta da declaração, no prazo estabelecido, importará em presunção de jure da má fé, sujeitando o funcionário às penas da legislação em vigor, presumindo-se boa-fé nos que a produzirem tempestivamente.

4.15 - Exame prioritário dessas declarações pelo DASP, para fazer cessar, sem demora, as situações ilegais.

4.16 - Definição das responsabilidades de chefes de serviço e órgãos pagadores que tiverem conhecimento de transgressões das normas proibitivas e contribuírem para sua ocultação.

4.17 - Obrigatoriedade de todos que recebem sòmente de uma fonte dos cofres públicos de declarar, por escrito, ao respectivo órgão pagador essa circunstância, sob as penas de lei cominadas para a falsidade ideológica.

4.18 - Revisão do texto constitucional para adptá-lo às conveniências e necessidades da Administração.

5 - Revisão do Estatuto dos Funcionários e da regulamentação correspondente.

5.1 - Constituição de Comissão Especial de alto nível para revisão do Estatuto dos Funcionários e elaboração do Código do Servidor Público.

5.2 - Estabelecimento da unidade do regime jurídico do pessoal civil da Administração Pública, sem prejuizo de normas peculiares aplicáveis a pessoal temporário, cuja admissão deve ser restringida ao mínimo. 
5.3 - Organização e instalação do Conselho Federal de Administração de Pessoal, com vistas à definição das linhas diretrizes da política de pessoal, a ser seguida com continuidade.

5.4 - Estudo pelo referido Conselho da situação do pessoal auxiliar dos Podêres Legislativo e Judiciário mediante análise das respectivas funções e do seu regime de direitos e vantagens, com o objetivo de encontrar fórmulas para correção de distorções e das disparidades de tratamento, evitandose, outrossim, a competição desigual dos três Podêres no processo de recrutamento de pessoal civil no mercado de trabalho de que resulta a perda pelo Executivo de elementos categorizados, não raro de formação adquirida na Administração Pública.

6 - Reaparelhamento e reestruturação do DASP.

6.1 - Instalação definitiva do DASP na Capital da República, como um dos poucos órgãos que pode $e$ deve para ali se transferir, dados o seu quadro re.lativamente pequeno, a circunstância de já dispor de instalações oficiais satisfatórias e, especialmente, a de encontrar em Brasília condições ideais para o exercício de suas funções de assessoramento ao Presidente da República, afastado de pressões de interêsses mais próximos e em clima propício ao estudo tranqüilo dos problemas.

6.2 - Manutenção na Guanabara, e outros grandes centros, apenas de agências de recrutamento e seleção do DASP, bem como de cursos de aperfeiçoamento, sem prejuízo dos de Brasília.

6.3 - Reestruturação do quadro de pessoal do DASP, para recuperação do seu índice de eficiência técnica.

6.4 - Retôrno de grande contingente de pessoal especializado daquele Departamento, afastado há longos anos, ou desligamento definitivo do seu Quadro.

6.5 - Reconstituição do Cadastro de Pessoal, criminosamente devastado, que faz com que se verifique essa situação verdadeiramente incrivel $e$ inadmissível: Não há um só órgão da administração 
federal que disponha de dados completos e atualizados, sôbre o número de servidores públicos, sua distribuição por níveis salariais, funções, idade, sexo, categoria funcional, órgãos do serviço público etc.

6.6 - E imprescindivel não só a restauração urgente dêsse Cadastro que é de importância capital para qualquer estudo sério, relativo a problemas de Administração de Pessoal, mas que êle tenha condições de manter-se sempre inteiramente atualizado, como em tempos passados ocorria.

6.7 - Recomposição da estrutura organizacional do DASP para que possa dar desempenho às importantes atribuições que lhe competem.

6.8 - Restabelecimento da posição que lhe é conferida pelo artigo 32 do Decreto-lei n? 200, de 25 de fevereiro de 1967 , sem a qual não poderá cumprir a missão relevante de "órgão central do sistema de pessoal, responsável pelo estudo, formulação de diretrizes, orientação, coordenação, supervisão e contrôle dos assuntos concernentes à Administração do Pessoal Civil da União". 
